\title{
Mehmet Tevfik Bey’in 1917 yılı Hendek Orman Fidanlığı raporu ve önemi
}

\author{
1917 Report of Mehmet Tevfik Bey on Hendek Forest Nursery and its importance
}

\author{
Erhan KILIÇ ${ }^{1}$ \\ Mustafa YILMAZ 2
} ${ }^{1}$ İstanbul Orman Bölge Müdürlüğü, İstanbul
${ }^{2}$ Bursa Teknik Üniversitesi, Orman Fakültesi,
Bursa

Sorumlu yazar (Corresponding author) Erhan KILIÇ

erhankilic@ogm.gov.tr

Geliş tarihi (Received)

22.07.2019

Kabul Tarihi (Accepted)

14.10.2019

\section{$\ddot{O} z$}

1916 yılında yabancı uzmanların öncülüğünde kurulan Hendek (Sakarya) Fidanlığı dönemin Orman Genel Müdürü Mehmet Tevfik Bey tarafından 1917 yılında ziyaret edilmiştir. Mehmet Tevfik Bey, Hendek Orman Fidanlığı'nı örnek alarak ve başka yerlerde tesis edilecek fidanlıklara altlık olması amacıyla ayrıntılı bir rapor düzenlemiştir. Orman Mektebi Alisi Mecmuasında yayınlanan ve ormancılık tarihimiz açısından önemli bir yere sahip bu raporda, fidanlık kuruluşu, gerekli alet-edevat ile tüm iş ve işlemler için maliyet hesapları yapılmıştır. Raporda, altı farklı üretim varsayımına göre karaçam ve meşe fidanları için üretim maliyet analizleri çıkarılmıştır. Mehmet Tevfik Bey, maliyet hesaplamalarında farklı seçenekleri dikkate almıştır. Bugün dahi genellikle ihmal edilen ihtimallere göre karar vermeyi önemsemiş ve muhtemel maliyet aralığını hesaplamıştır. Çalışmada, örnek gösterilen bir hektarlık fidanlık kuruluş harcamaları ve fidan üretim maliyetleri günümüz birim fiyatlarına göre tekrardan irdelenmiştir. Bugünkü karaçam ve meşe fidanı üretim tekniğiyle, rapor dönemi üretim yaklaşımı karşılaştırılmıştır. Çalışma sonucunda, 1917 yılı kuruluş ve üretim maliyetlerinin 2019 yılı maliyetlerine yakın olduğu, üretim tekniklerinde de birçok bakımdan benzediği anlaşılmaktadır.

Anahtar Kelimeler: Hendek, orman fidanlığı, ormancılık tarihi

\section{Abstract}

Hendek Forest Nursery, established in 1916 under the leadership of foreign experts, was visited by Mehmet Tevfik Bey, General Director of Forestry in 1917. Mehmet Tevfik Bey prepared a detailed report for the nurseries to be established in other places with the example of Hendek Forest Nursery. In this report, published in the Journal of Forestry School, which has an important place in our history of forestry, cost calculations have been made for the nursery establishment, necessary tools and equipment and all works and transactions. In the report, production cost analyzes for the seedlings of black pine and oak tree species were made according to six different production scenarios. Mehmet Tevfik Bey has considered different options in the cost calculations. He cared about making decisions on the possibilities that are often neglected even today and calculated the estimated cost range. An example of one-hectare nursery establishment expenditures and seedling production costs were examined once again according to the current unit prices. The production techniques of black pine and oak tree seedlings are compared with the production approach of the reporting period. As a result of the study, it was understood that establishment and production costs of 1917 were close to those of 2019 and the production techniques were similar in many ways.

Keywords: Hendek, forest nursery, history of forestry
Atıf (To cite this article): KILIC, E, YILMAZ, M . (2020). Mehmet Tevfik Bey'in 1917 Y1lı Verilerine Göre Hendek Orman Fidanlığı Raporu ve Öne-
mi. Ormancılık Araștırma Dergisi , 7 (1), 49-61 . DOI: https://doi.org/10.17568/ogmoad.595116 


\section{Giriş}

Bugün itibarıyla Türkiye, ormanc1lık faaliyetlerinin birçok kolunda dünyanın önde gelen ülkelerinden biri durumundadır. Orman fidanlıkları ve fidancılık faaliyetleri de bu alanlardan biridir. Başlangıçta ve gelişim aşamalarında sınırlı imkanlarla çetin yollardan geçerek mevcut seviyeye ulaşılmıştır. Günümüzde orman fidanlıklarımız modern imkânlara sahip olup, sessiz sedasız çok anlamlı ve değerli görevleri yerine getirmektedir. Bu fidanlıklar kırsaldaki ağaçlandırmalar ve kentlerdeki bitkilendirmelerin ana tedarik kaynağı durumundadır.

Orman Genel Müdürlüğü, 3.290 hektar alanda kurulmuş, 137 adet orman fidanlığında başta karaçam, sarıçam, kızılçam ve fıstıkçamı vb. türler olmak üzere ibreli ve yapraklı orman ağacı türleri ile süs bitkilerinden oluşan 688 değişik türde fidan üretimi yapmaktadır. Böylece her y1l 300 milyonun üzerinde fidan üretimi ve bakımı gerçekleştirilmektedir (OGM, 2018).

Türkiye'de ilk orman fidanlıklarının kuruluşu küçük alanlarda, az sayıda türde, sınırlı bir fidan üretimi ile olmuştur. Günümüzde gelinen seviyeyi iyi anlamak için ilk orman fidanlıklarının durumunu ve imkanlarını yakından tanımak gerekmektedir. Ormancılık tarihimizde Hendek Fidanlığı ilk kurulan fidanlık olmamakla birlikte, hakkında en ayrıntılı bilgi sahibi olduğumuz en eski fidanlıktır. Hendek fidanlığı başlangıçta 9,0 hektar olarak düşünülmüş ve ilk aşama olarak 3,0 ha bölümünde fidanlık tesis edilmiştir. Çalışmalar tamamlandıktan sonra tesis edilen fidanlığa dönemin bakanı Mustafa Şeref Bey’in ismi verilmiştir (Ortaç, 1945). Bununla birlikte Hendek Orman Amenajman Planı incelendiğinde mevcut fidanlık alanının 1,2 ha olduğu anlaşılmaktadır (Anonim, 1918a).

Bu çalışmada, Orman Umum (Genel) Müdürü Mehmet Tevfik Bey’in 1917 yılında hazırladı̆̆ Hendek Orman Fidanlığı Raporu temel alınarak ülkemizdeki fidanlık çalışmaları tarihinin meslek kamuoyuna tanıtılması amaçlanmıştır. Ayrıca geçmişteki ve günümüzdeki fidanlıkların maliyet ve üretim yöntemleri karşılaştırılmıştır.

\subsection{Osmanlı dönemi fidanlık çalışmalarına genel bakış}

1856 yılında yayınlanan Islahat Fermanı'nda tarım ve ticaretin önündeki engellerin kaldırılması için bilim ve eğitimden faydalanılması istenmiştir. $\mathrm{Bu}$ kapsamda 1857 yılında Fransız ormancıların öncülüğünde İstanbul'da eğitim hayatına başlayan Orman Mektebi, birkaç yerleşke değiştirdikten sonra 1893 yılında Halkalı’ya (İstanbul-Küçükçekmece) taşınarak Ziraat Mektebi ile birleşmiştir. Ancak Halkalı civarında eğitim yapılabilecek bir ormanın olmaması fidanlık kuruluşunu zorunlu hale getirmiştir (Anonim, 1893). Bu sebeple 1894 yılında Halkalı Ziraat Mektebi içerisinde ülkemizin ilk fidanlığg kurulmuştur. Ayrıca gerekli ödenek sağlandıktan sonra ilk teknik ağaçlandırmalar da okul civarında yapılmıştır.

Yine aynı yıllarda Anadolu Şimendifer Demiryolları Kumpanyası (Şirketi) tarafından İstanbul-Ankara arasındaki istasyon ve güzergâhın ağaçlandırılması için Büyükderbent (Kocaeli-Kartepe) ve Adapazarı'nda fidanlık kurulmuştur. 1894 yılında hat civarındaki zirai faaliyetleri inceleyen Bonn (Almanya) Ziraat Fakültesi hocası Herrmann (1894) benzer bir fidanlığın Mekece (Sakarya-Pamukova) istasyonuna da kurulmasını tavsiye etmiştir.

24 Nisan 1900 tarihinde Orman Heyet-i Fenniyesi (Fen Heyeti) tarafından düzenlenip Şura-yı Devlet'e gönderilen bir raporda ise ormanların yangınlardan korunması ve yeni ormanlar yetiştirilmesi için gerekenler ayrıntılı bir şekilde anlatılmıştır (Anonim, 1900). Raporda İstanbul'a gelen suların kirlenmesi sebebiyle boşaltılmış Belgrad ve Kömürcü köylerine ait arazilerde sekiz-dokuz bin dönümlük ağaçlandırılma yapılmasının uygun olacağ ifade edilmiştir. Bunun için su bentleri civarında Belgrad köyü ve Bahçeköy'e (İstanbul-Sarıyer) yakın orman içinde bir tohumhane ve fidanlık kurulması gerektiği vurgulanmıştır. Tüm bu işlerin yapılabilmesi için 50.000 kuruş $^{1}$ kuruluş ödeneği ve yıllık bir fen memuru ile dört bekçinin maaşı için de ayrıca 43.200 kuruş hesap çıkarılmıştır.

1908 yılında ilan edilen İkinci Meşrutiyet sonrasında ormancılık tarihimizde önemli gelişmeler yaşanmıştır. 1911 yılında Halkalı Ziraat ve Ormancılık Mektebi'nden orman bölümü ayrılarak Bahçeköy'de müstakil bir okul olarak açılmıştır (Anonim, 1910). Ayn1 yıl Orman Heyet-i Fenniyesi, Orman Müdiriyet-i Umûmîyesi'ne (Orman Genel Müdürlüğü) dönüştürülmüştür (Anonim, 1911). Bu değişsim ve dönüşümlerin tümünde hiç şüphesiz Hoca Ali Riza Efendi'nin katkı ve iradesi etkindir (Kutluk ve Yund, 1950). 1912 yılında ormanların harita ve mülkiyet durumunu çıkarmak için teşkilata 10 adet harita memuru alınarak çalışmalara başlanmıştır (Kutluk, 1967). Ayrıca Belgrad ormanının işletme planı ve haritaları Stöger tarafından yapılmıştır (Anonim, 1918b). En önemli gelişmeler ise Bonn Üniversitesinde Ziraat eğitimi görmüş Mehmet Celal Bey'in 1913 yılında Ticaret ve Ziraat Nezareti’ne atanmasıyla başlamıştır.

1100 kuruş 1 Osmanlı lirası etmektedir. 
Nâzır Mehmet Celal Bey ilk iş olarak mevcut ormanları tahribattan kurtarmak ve çıplak alanları ağaçlandırmak için kolları sıvamıştır. Bu kapsamda 19 Şubat 1913 tarihinde "Orman Yetiştirilmek Üzere Vilayete Yazılan Tahriratı Umumiye” isimli bir belge hazırlanarak tüm vilayetlere gönderilmiştir (Anonim, 1913a). Belgede, ormanların kötü muameleye maruz kaldığı ve bunun sonucu olarak erozyon ve sel baskınlarının yaşandığ 1 , halkın tezek yaktığı ve bilakis bu organik gübrenin tarımda lazım olduğu ifade edilmiştir. Çözüm olarak her yerleşim yerinde üç beş dönümlük sulanabilir arazi ayrılarak, fidanlık kurulması ve masrafların da karşılanması istenmiştir. Ayrıca bu talimat ile yetinilmeyip ağaçlandırma, fidanlık ve ağaç bayramı için kanun teklifi verilmiştir. Orman Umum Müdürlüğü tarafından köy ve kasabalarda orman yetiştirilmesi için "Orman Yetiştirmek Usulü” isimli talimat kitapçığı basılarak dağıtımı sağlanmıştır (Anonim, 1913b). Aynı yıl Bahçeköy'de Orman Mektebi Alisi yakınına küçük bir fidanlık kurulmuştur (Diker ve İnal, 1945). Ancak kısa süre sonra Mehmet Celal Bey'in nâzırlıktan ayrılması ve Hoca Ali Rıza Efendi'nin de emekli olması, planlanan işleri kesintiye uğratmıştır.

Dünya çapında gerginleşen siyasi ortam ve beraberinde ortaya çıkan savaş tehdidi Osmanlı hükümetini çeşitli arayışlara sürüklemiştir. Bu sebeple ormancilıktan ciddi gelirler bekleyen yetkililer, Orman Umum Müdürlüğü makamına yabancı bir uzmanın getirilmesini düşünmüş, ancak aranan vasıfta uzman bulunamayınca 21.09.1913 tarihinde ziraat kökenli Nesib Bey bu göreve atanmıştır. Fakat Nesib Bey uzun süre görevde kalamadan 28.10.1913 tarihinde azledilmiş (Anonim, 1913c) ve Umum Müdürlük görevi vekaleten Mehmet Tevfik Bey’e verilmiştir. Kısa bir süre sonra 1914 yılının Mayıs ayında Avusturya'dan Alman kökenli uzman ormancı Hermann Veith ülkemize davet edilmiştir (Anonim, 1914).

Orman Müşaviri olarak göreve başlayan Veith, ilk iş olarak Karadeniz, Ege ve Akdeniz ormanlarını gezerek inceleme raporları hazırlamış ve nezarete teslim etmiştir. Bu raporlarda mevcut ormanların sürdürülebilir bir şekilde yönetilmesi, daha verimli faydalanılması için çözüm ve çareler önerilmektedir. Veith'in önerilerinden biri de ağaçlandırma yapmaktır. Veith, yaklaşık bir yıl sonra, beklenen çözümleri gerçekleştirmek üzere bazı ormancılık projeleri hazırlayarak uygulamaya konulmasını sağlamıştır. Projelerin daha kolay gerçekleştirilmesi için yerli ve yabanc1 teknik elemanlardan ekipler kurmuştur. Bu yıllarda, bir taraftan Hendek ormanlarında amenajman çalışmaları yapılırken, diğer taraftan Kazimiye (Müslümcedit) köyünde Orman Ameliyat
Mektebi ile yakınında bir fidanlık ve tohumhane tesis edilmiştir. Yabancı teknik ekibin içinde yer alan Franz Stumpfohl'un fidanlık bilgisinin üst düzeyde olduğu görülmektedir. Devam eden Birinci Dünya Savaş'ına rağmen, 1916 yılının sonlarında Hendek Orman Ameliyat Mektebi'nde öğretmenlik yapan Mehmet Latif Bey, Almanya'daki fidanlıkları incelemek üzere yurtdışına gönderilmiştir (Anonim, 1916a). Ayrıca Franz Stumpfohl, fidanlığın ertesi yıla kalan işleri için bir program hazırlamış ve Ticaret ve Ziraat Nezareti'ne teslim etmiştir. Bunun üzerine nezaret, kalan işleri tamamlamak üzere fen memurları dahi görevlendirmiştir (Anonim, 1916b). 1917 yılının baharında Orman Umum Müdürü Mehmet Tevfik Bey Hendek Fidanlığı'nda yapılan çalışmaları detaylı bir şekilde incelemiş ve maiyetinde bulunan teknik elemanlarla birlikte, uzun bir rapor tanzim etmiştir.

Hendek'te fidanlık ve tohumhanenin kurulmasındaki asıl amaç öğrencilerin tatbikat yapması ve İstanbul başta olmak üzere şehirlerin ağaçlandırılması için gereken fidanları yetiştirmektir. Bu bakımdan, fidanlığın bilimsel bir şekilde işletilmesi için Orman Müşaviri Hermann Veith'in tavsiyesi ile 1918 yılında Avusturya'dan Antonaç isimli bir uzman davet edilmiştir ve kendisiyle beş yıllık bir anlaşma yapılmıştır. İyi bir işletmeci ve fidancı olan Antonaç, Mondros Mütarekesi sebebiyle görevine başlayamadan ülkemizden ayrılmak zorunda kalmıştır (Kutluk, 1957). Ardından tehcir sebebiyle köylerinden ayrılan köylülerin geri dönmesiyle Orman Ameliyat Mektebi 1918 yılının Aralık ayında zorunlu olarak Adapazarı'na taşınmıştır (Anonim, 1918c). Bu tarihten sonra mektep, fidanlık ve tohumhane köylülerin eline geçmiştir.

\subsection{Mehmet Tevfik Bey (Ortaç)}

1876 yılında Selanik’te doğmuştur. İlk ve orta tahsilini Selanik Rüştiye ve İdâdîsinde yapmıştır. 1894 yılında Ziraat Mektebi Alisi'ne girmiş ve 1898 y1linda mezun olmuştur. İlk olarak Selanik Ziraat Mektebi Muallim Yardımcılığı'na atanmış, bir süre çalıştıktan sonra, asaleten muallimlik yapmaya başlamıştır. 2 Mayıs 1900 tarihinde 540 kuruş maaşla Selanik Orman Müfettiş Yardımcılığg Kontrol Memurluğu'na tayin olmuştur. 5 Haziran 1905'te 900 kuruş maaşla Serez ve Drama Orman Müfettişliği'ne, 15 Ekim 1908'de 1.900 kuruş maaşla, Selanik Merkez Sancağı Orman Müfettişliği’ne atanmış, ancak Selanik'in işgal edilmesi üzerine İstanbul'a tayin edilmiştir. Mehmet Tevfik Bey, 26 Ağustos 1913'te 3.000 kuruş maaşla Ticaret ve Ziraat Nezareti İdaresi Merkez Müdürü olmuştur. Bu dönemde vekaleten Orman Umum Müdürü (Şekil 1) olarak görevini yürütmüş ve 19 Mayıs 1917 'de 
maaşı 3.500 kuruşa yükseltilmiştir (Yund, 1959). Ardından 11 Mayıs 1918'de 5.000 kuruş maaşla bu kez asaleten Orman Umum Müdürü olarak atanmiştır (Anonim, 1913d).

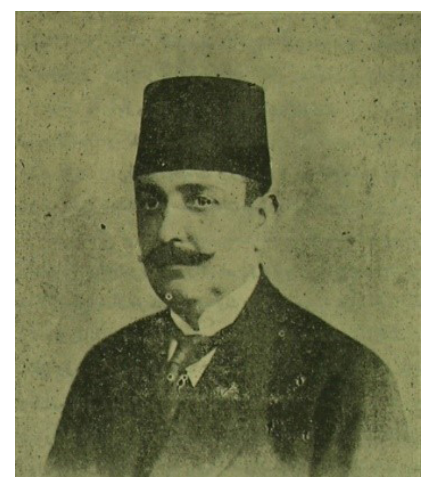

Şekil 1. Orman Umum Müdürü Mehmet Tevfik Bey (İhsan, 1917)

Figure 1. General Director of Forestry Mehmet Tevfik Bey (İhsan, 1917)

Mehmet Tevfik Bey’in Genel Müdürlüğü döneminde Hendek fidanlığgndan sonra Eskişehir'de bir fidanlık kurulmuş, Ankara ve Konya fidanlığı için de yer bakılmıştır. Ayrıca Kağıthane Deresi, Hacıosman Bayırı ve Hadımköy sırtlarına ağaçlandırmalar yapılmıştır. Ancak Mondros Mütarekesi sonrasında iktidara gelen Hürriyet ve İtilaf Fırkasının yöneticileri tarafından 20 Şubat 1919 tarihinde görevinden azledilmiştir (Anonim, 1919). Başta Hendek Süleymaniye Ormanı'na ait ihale olmak üzere, birçok çalışmaya fesat karıştırdığı gerekçesiyle hakkında şikâyetler yapılmıştır. Husumete dayandığı sanılan bu şikâyetlere rağmen, 17 Ağustos 1921 Şura-yı Devlet kararıyla, tüm ithamlardan aklanmıştır (Anonim, 1921). Mehmet Tevfik Bey, Cumhuriyet döneminde İstanbul Belediye Meclis Azası görevini yürütmüştür. Soyadı kanunuyla birlikte Ortaç soy ismini alan Mehmet Tevfik Bey 26 Kasım 1946 vefat etmiştir (Yund, 1959).

\section{Materyal ve Yöntem}

Çalışma için İstanbul Üniversitesi-Cerrahpaşa Orman Fakültesi kütüphanesinde bulunan 1917 tarihli Orman Mektebi Alisi Mecmuasının üçüncü say1sında dönemin alfabe ve Türkçesiyle yayınlanan Orman Umum Müdürü Mehmet Tevfik Bey'in "Fidanlık Tesisi" adlı raporu incelenmiştir. Diğer tarihi vesikalar T.C. Cumhurbaşkanlığı Devlet Arşivleri Başkanlığına bağlı Osmanlı Arşivinden taranarak temin edilmiştir. Döneme ait gazeteler Milli Kütüphane, Beyazıt Devlet Kütüphanesi Hakkı Tarık Us Koleksiyonu ve Atatürk Kitapl1ğından taranmıştır. Osmanlı Türkçesiyle yazılmış tüm belgelerin günümüz Türkçesine tercümesi ve sadeleştirilmesi tarafımızdan yapılmıştır.

Tevfik Bey'in fidanlık raporunda geçen hesaplamaların günümüze göre parasal karşılaştırmaları altın endeksine göre yapılmıştır. Birinci Dünya Savaşı ve Milli Mücadele döneminde 1 Osmanlı lirası (100 kuruş) 6,615 gramdır (Ergin, 2017). 1 gram altının bugünkü ortalama satış fiyatı 250 Türk lirası kabul edildiğinde, 1 Osmanlı lirası yaklaşık 1.653 Türk lirasına denktir. Bu durumda 1 Osmanlı kuruşu da günümüzün 16,53 Türk lirasına karşılık gelmektedir. Hesaplamalarda parasal dönüşüm endeksi olarak 16,53 rakamı kullanılmıştır.

Fidan üretim bedellerinin karşılaştırılmasında ise Orman Genel Müdürlüğü'nün kurumsal internet sitesinde yayınlanan fidan bedelleri esas alınmıştır (OGM, 2019a). Diğer rayiçler Orman Genel Müdürlüğü Ağaçlandırma Rehabilitasyon, Toprak Muhafaza, Erozyon ve Sel Kontrolü, Mera Islahı, Kavak Ağaçlandırması, Fidanlık, Silvikültür ve Etüt Proje Birim Fiyat Cetveli (OGM, 2019b) ile Çevre ve Şehircilik Bakanlığı, İnşaat ve Tesisat Birim Fiyatları (ÇSB, 2019a) ve Yapı Yaklaşık Birim Maliyetleri Hakkında Tebliği (ÇSB, 2019b) esas alınarak hesaplanmıştır.

Bunun yanında, günümüz fidanlık kuruluşu için arazi bedelinin tespitinde büyük zorluklar bulunmaktadır. Arazinin bulunduğu coğrafi bölge, bulunduğu il, yola yakınlığı, su durumu vb. birçok husus bedel tespitini güçleştirmektedir. Bilimsel olarak fidanlık kurulacak arazinin şartları (rakım, arazi eğimi, bakı, yol, su, vb.) göz önüne alınarak, başta belediye ve emlak işi yapan esnafla görüşülerek herkesin kabul edeceği makul bir bedel yazılmıştır. Ayrıca geçmişte işçi ile yapılan birçok iş kolu bugün makineli olarak yapıldığı için, makineli birim fiyatlar esas alınmıştır.

\section{Bulgular}

\subsection{Mehmet Tevfik Bey'in fidanlık raporu}

Mehmet Tevfik Bey'in düzenlediği fidanlık raporu iki ana bölümden oluşmaktadır. Birinci bölümde fidanlık kurulmasıyla alakalı genel bilgiler verilmiş, kuruluş maliyeti ve gerekli alet edevat çıkarılmıştır. İkinci bölümde ise altı farklı üretim varsayımları ve buna bağlı üretim maliyetleri hesaplanmıştır. Ayrıca Mehmet Tevfik Bey, konunun daha iyi anlaşılması ve maliyetlerin doğru çıkarılması için raporun giriş bölümüne "Bu rapor, bir hektar genişliğe sahip araziye göre muhtelif cins orman ağacına mahsus fidanlık tesisi ve idaresine göre hazırlandığından, ağaçlandırma amaciyla fidanlık kurmak isteyenlerin hesaplarını buna göre yapmalarını tavsiye ederiz" şeklinde bir açıklama eklemiştir (Mehmet Tevfik, 1917). 


\subsubsection{Fidanlık kuruluşu ve maliyet hesapları}

Mehmet Tevfik Bey (1917), kuruluş ve maliyet hesaplarına geçmeden önce "Fidanlik, tarıma elverișli veya elverişsiz muhtelif arazide, tohum dökülmesiyle gençlik elde edilemeyen ormanlarımızda ve tahribata uğramış bölümlerinde, yapay olarak orman yetiștirmek amaciyla veya parklara, özel bahçelere, tren ve yol güzergahlarına dikilecek ağaçları tohumdan meydana getirmek üzere hazırlanan özel alanlara fidanlık denir" şeklinde bir tanımla raporuna başlamıștır. Devamında, fidanlık yer seçimi için önemli iki hususu dile getirmiştir. Mehmet Tevfik bey, fidanlıklarda tohumların çimlenmesi, sicak mevsimlerde kuraklıktan korunmas1 ve büyümelerini sağlamak için gereken suyun kolayca elde edilmesi için, kuruluş yerinin ırmak kenarında veya su kaynağının civarında olmasını önermektedir. İkinci olarak, üretilen fidanların, ihtiyaç duyulan yerlere rahat gönderilmesi ve dağıtılması için deniz ve kara ulaşım imkânlarına yakın yer seçilmesini tavsiye etmiştir.

Mehmet Tevfik Bey, ziraate elverişli arazi, işlenmemiş boş arazi veya açıklıklar ile tahribata uğramıș orman arazisinde gerekli şartları üzerinde bulunduruyorsa, Fidanlık kuruluş aşamasında yapılacak zorunlu harcamaları şu şekilde sıralamıştır.

1-Arazi bedeli: Osmanl ülkesinde işlenmemiş boş arazi ve açıklıklar ile orman arazisi hazineye ait olmasindan dolayl, bu tür arazide fidanlık kurmak için bir bedel vermek gerekmemektedir. Ancak özel arazi satın alınarak fidanlık yapılacaksa, memleketimizin değișik yerlerinde bir hektar büyüklüğündeki arazi için 1.000-3.000 kuruş arasında bir bedel ödemek gerekir.

2-İslenmemiş boş arazi ve açıkliklarda fidanlık kurulmasl gerektiğinde üzerindeki ot ve çallıkların kaldırılması için 15-30 çalış̧anın gündeliği olarak 300-600 kuruş harcamak gerekir.

3-Tahribata uğramıș orman arazisinde, fidanlık kurmadan önce yerin hazırlanması, örtü temizliği ve bakımı gerekir. Bunun için mevcut kütük ve tahrip edilmiş ağaçların sökülmesi ve sahanın işlenmesi için 20-40 çalıșanın gündelik bedeli olarak 400-800 kuruş ödemek gerekir.

4-Orman arazisinin örtü temizliğinden sonra, geriye kalan ot, çöp, dal vb. atıkların toplanarak yakılması gerekir. Toprak yapısına bağlı olarak, bu ișe 40-60 yevmiye ve 800-1.200 kuruş harcamak gerekebilir.

5-Üç kısım araziden hangisinde olursa olsun, her birine ait aşağıldaki işlemler yapıldıktan sonra, 30$40 \mathrm{~cm}$ derinliğinde krizma (toprak işleme) yapılmasl gerekir. Memleketimizde bir hektar arazinin bu derinlikte toprak işlemesi için, bir iş̧̧i 25-30 metre toprak işlemesi yapabileceğine göre, toplamda 300-400 yevmiye eder. Yani toprak işlemesi için 6.000-8.000 kuruş harcama yapılması gerekir.

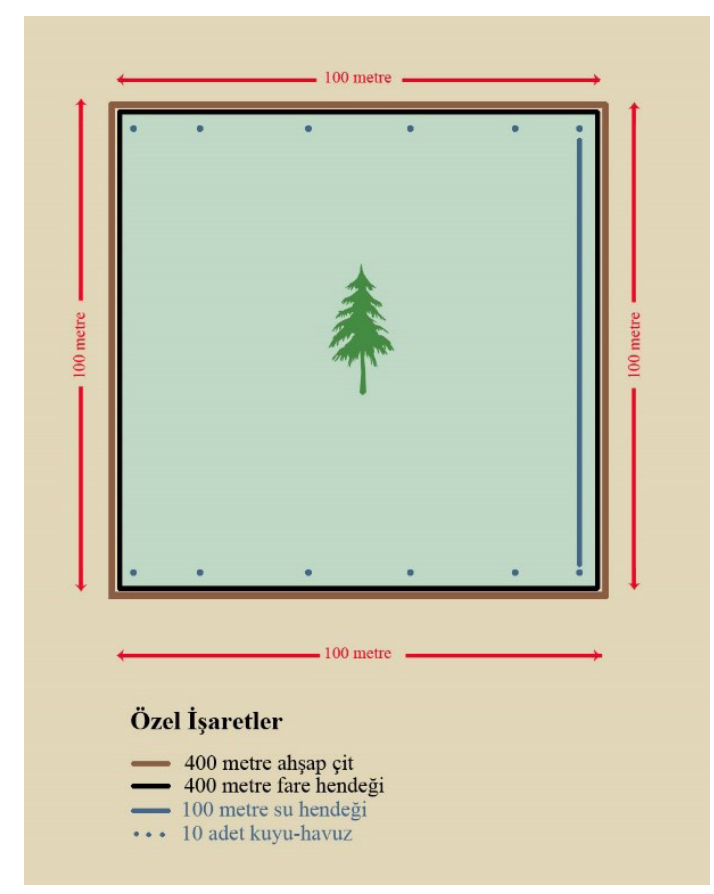

Şekil 2. Fidanlık alanı vaziyet planı

Figure 2. Nursery site layout plan

6- Su yolu hendeği için 100 m uzunluğunda, $30 \mathrm{~cm}$ genişliğinde ve $50 \mathrm{~cm}$ derinliğinde kazllmastyla birlikte 15 metreküp toprağın çıkarılması gerekir. Çıkarılan toprağın fidanlıktan yüz metre uzak bir yere taşınması düşünülürse, bu iş için 8-12 yevmiye ve 160-240 kuruş gerekir. Bundan başka killi zeminde yapılacak 10 adet kuyunun yapımı için de 10-12 yevmiye, 200-240 kuruş lazımdır. Kumsal arazide kuyunun kazılması mümkün olamayacağtndan, yapılacak 10 adet bir metre derinliginde bir buçuk metre çapında havuz için de, 500 kuruştan olmak üzere 5.000 kurus malzeme bedeli gerekir. Yapllacak iş ve işlemler Şekil 2'de bulunan vaziyet planında gösterilmiştir.

7-Fidanlı̆̆ farelerin istilasından korumak için etrafina $50-100 \mathrm{~cm}$ derinliğinde ve $50 \mathrm{~cm}$ genişliginde hendek kazılmasl gerekli olup, söz konusu hendeğin dört tarafl toplam uzunluğ 400 metre olacağına göre 100-200 $\mathrm{m}^{3}$ toprağın çıkarılması için 50-100 yevmiye ve 1000-2000 kuruş harcamak gerekir.

8-Ahşap parmaklık, 400 adet parmaklık direğinin toprağa çakılması ve yatay raptiyeler ile parmaklık çıtalarının mihlanması için 40-50 yevmiye ve 8001.000 kuruşa ihtiyaç vardır. 
9-250 cm uzunluğunda ve $10 x 10 \mathrm{~cm}$ ebadında 400 adet direk ile $400 \mathrm{~cm}$ uzunluğunda 200-220 adet yatay raptiye ve $180 \mathrm{~cm}$ uzunluğunda 4.000-5.000 adet parmaklık çıtalarının kesilmesi ve taşınması, ayrica direklerin her bir adeti 10 kuruş ve raptiyelerinki 8 kuruş ve çıtaların 1.000 tanesi 1.000 kuruştan olmak üzere, toplam 9.600 kuruşa yapılabilir. Veyahut direkleri $10 \mathrm{~m}^{3}$ ve yatay raptiyeler 4 metreküp ve çitalar 7,2 $\mathrm{m}^{3}$ hacminde bulunduğundan, metreküp hesabiyla, direk ve raptiyelerin her bir metreküpü 400 kuruştan ve parmaklık çıtalarınınki 600 kuruştan; toplam 9.920 kuruşla satın alınması mümkündür. Kullanılması gerekli 100 $k_{\text {klyye }}^{2}$ çivi için de 5.000 kuruş lazımdır. Ahşap çitin aksamı Şekil 3'te gösterilmiş̧tir.

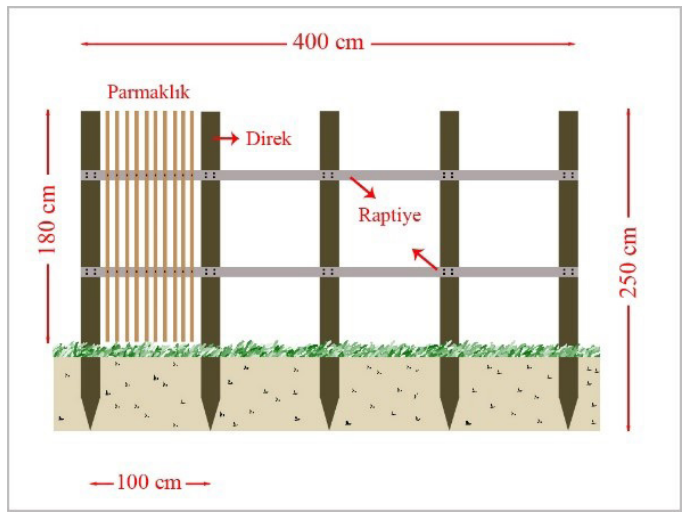

Şekil 3. Fidanlığın etrafına yapılması planlanan ahşap çit Figure 3. Wooden fence planned to be built around the nursery

10- Fidanlı̆̆ın parsellere bölünmesi ve bunların kullanilır bir hale gelmesi için gereken 50-100 yevmiye için 1.000-2.000 kuruş lazımdır.

11- Ekim ve dikim için 16-20 yevmiye ve 320-400 kuruş gerekir.

12- Parsellerin çapalanması ve yollar ile hendeklerin düzenlenmesi için 250-300 kadın yevmiyesine ihtiyaç olup, bunun için 3.750 - 4.500 kuruş harcamak lazımdır.

13- Fidanlık için gereken alet ve edevat Tablo 1'de ayrıntılı olarak gösterilmiştir.

14-Koruma kafesleri için gereken pervaz ve ızgara tahtaları ile bunların yapımı ve çivisi için 3.0005.000 kuruş gerekir.

15-Alet, edevat ve tohumlarl güzel bir şekilde korumak için fidanlık içinde veya yakınında bir kulübe yapılması zorunludur.

21 Kıyye 1.282 grama denk ölçü birimi
Tablo 1. Fidanlık için gereken alet ve edevat listesi Table 1. List of tools and equipment required for nursery

\begin{tabular}{|c|c|c|}
\hline Cins ve nevi & Adet & $\begin{array}{c}\text { Toplam } \\
\text { fiyatı } \\
\text { (kuruş) }\end{array}$ \\
\hline Özel Kürek ve Bel & 10 & 300 \\
\hline $\begin{array}{l}\text { Normal Kürek ve çeşitli büyük- } \\
\text { lükte Bel küreği }\end{array}$ & 30 & 600 \\
\hline$*$ & 10 & 230 \\
\hline Kazma ve çapa & 20 & 500 \\
\hline Tirmık & 10 & 250 \\
\hline Ufak çapa & 10 & 150 \\
\hline Orak & 5 & 100 \\
\hline Çizgi merdanesi & 20 & 200 \\
\hline Balta & 3 & 70 \\
\hline Testere & 2 & 60 \\
\hline Burgu & 1 & 50 \\
\hline Rende & 1 & 50 \\
\hline $\begin{array}{l}\text { Tornavida, taş kalemi, taşçı çekici, } \\
\text { keser }\end{array}$ & 1 & 150 \\
\hline $\begin{array}{l}\text { Yüz metre uzunluğunda tel (etiket } \\
\text { için) }\end{array}$ & 1 & 150 \\
\hline Tohum ekimi için özel alet & 5 & 100 \\
\hline Mibzer & 15 & 150 \\
\hline Özel mibzer & 10 & 100 \\
\hline Tarım makinesi & 1 & 200 \\
\hline Fidan dikim makinesi & 1 & 1.000 \\
\hline Fidan dikim aleti & 2 & 500 \\
\hline İp ve çivi vesaire & 1 & 250 \\
\hline Marpuçlu (hortumlu) el tulumbası & 1 & 1.500 \\
\hline Taşıma giderleri & 1 & 2.500 \\
\hline Toplam & & 9.160 \\
\hline
\end{tabular}

* Okunamadı, ancak birim fiyatına göre kürek ve tırmık değerinde bir alet

Bu kulübenin bölümleri: fidanlarl güneşten korumak için üstü bezle kapalı bir bölüm, işçilerin tümünü alacak büyüklükte bir bölüm ve fidanlık memurunun oturacağl toplam üç oda ve tohumların saklanacă̆ sağlam yapılı bir bodrumdan ibarettir. Söz konusu kulübenin inşasl, yerine göre değişmekle birlikte 7.500-10.000 kuruş ihtiyaç gösterir. Tohum ekiminden önce yapılan harcamanın ayrıntılı özeti Tablo 2'de verilmiştir.

\subsection{2. Üretim varsayımları ve maliyet hesapları}

\section{Birinci üretim varsayımı ve maliyet hesabı}

Mehmet Tevfik Bey, birinci üretim varsayımında 2 yaşında karaçam fidanı yetiştirmenin maliyet hesabını yapmıştır. Ayrıca her sene fidan alın- 
mak istenirse, parselin yarısına ekim yapılarak kesintisiz fidan alınabileceğini ifade etmiştir. Karaçam tohumlarının memleketin her yerinde bolca bulanabileceğini, ancak tohumların bekçi veya bekçi başıları tarafından özenle toplanmasını istemiştir. Yapılacak harcamaların tümü Tablo 3'te gösterilmiştir. Bu hesaba göre en düşük maliyette 500.000 fidan üretilirse 1.000 fidan bedeli en az 23,27 kuruş veya en yüksek 34,25 kuruş olarak hesaplanmıştır. Şayet 1.500 .000 fidan üretilirse maliyetin düşeceğini ve 1.000 fidanın maliyetinin 7,76-11,41 kuruş arası olacağı hesaplanmıştır.

Tablo 2. Fidanlığın kuruluş aşamasında yapılacak zorunlu masraflar

Table 2. Necessary expenses to be made during the establishment stage of the nursery.

\begin{tabular}{lcr}
\hline Yapılacak işin cinsi & $\begin{array}{c}\text { Yevmiye } \\
\text { miktarı }\end{array}$ & $\begin{array}{c}\text { Maliyet bedeli } \\
\text { (kuruş) }\end{array}$ \\
\hline Arazi Bedeli & - & $1.000-3.000$ \\
Ot alma & $40-60$ & $800-1.200$ \\
$\begin{array}{l}\text { Toprak işleme } \\
\text { Su yolu ve kuyuların } \\
\text { kazılması }\end{array}$ & $300-400$ & $6.000-8.000$ \\
$\begin{array}{l}\text { Hendeğin kazılması } \\
\text { Parmaklık ve diğer tüm } \\
\text { ahşap malzeme }\end{array}$ & $50-100$ & $1.000-2.000$ \\
$\begin{array}{l}\text { Arazinin parsellere ay- } \\
\text { rılması ve hazırlanması }\end{array}$ & $50-50$ & $10.400-10.920$ \\
$\begin{array}{l}\text { Ekim } \\
\text { Çapalama ve temizlik }\end{array}$ & $16-20$ & $1.000-2.000$ \\
için kadın işçi & $250-300$ & $320-400$ \\
$\begin{array}{l}\text { Alet ve edevat } \\
\text { Kulübe inşaat masrafı }\end{array}$ & - & $3.750-4.500$ \\
\hline Toplam & - & $7.500-10.000$ \\
\hline
\end{tabular}

\section{İkinci üretim varsayımı ve maliyet hesabı}

İkinci üretim varsayımında $1.500 \mathrm{~kg}$ meşe tohumu kullanarak 2 yaşında meşe fidanı yetiştirilmesine göre hesap yapılmıştır. Buradaki hedef 200.000 ile 750.000 arası meşe fidanı üretmektir. Bu üretim için yapılacak harcamaların tümü Tablo 4'te gösterilmiştir.

Bu hesaba göre iki yaşında 200.000 meşe fidanı üretilirse 1.000 adedinin fiyat1 58,18-85,62 kuruş aras1 ve 750.000 fidan üretmek mümkün olursa 15,51-22,83 kuruş arası olacağını belirtmiştir.

\section{Üçüncü üretim varsayımı ve maliyet hesabı}

Mehmet Tevfik Bey, üçüncü üretim varsayımında iki yaşına kadar eşit sayıda karaçam ve meşe fidanının birlikte üretilmesi durumuna göre hesap ç1karmıştır. Bu üretimde fidanlığın 1/3’ü karaçam ve 2/3'ü meşeye ayrılmasını gerektiği vurgulamıştır. Fidan maliyetlerini, birinci ve ikinci üretim varsayımındaki rakamları esas alarak kapladıkları alanlara göre hesaplamıştır.

Tablo 3. Birinci üretim varsayımına (İki yaşında Karaçam Fidanı Üretmek) göre yapılacak zorunlu masraflar

Table 3. Necessary costs to be incurred on the first production assumption

\begin{tabular}{|c|c|c|}
\hline Çalışma konusu & $\begin{array}{l}\text { Yevmiye } \\
\text { adedi }\end{array}$ & $\begin{array}{c}\text { Yevmiye } \\
\text { tutar1 (kuruş) }\end{array}$ \\
\hline Tohum bedeli $(200 \mathrm{~kg})$ & - & - \\
\hline $\begin{array}{l}\text { Parsellerde ikinci defa } \\
\text { toprak işlemesi, taksimi ve } \\
\text { tesviyesi }\end{array}$ & $50-100$ & $1.000-2.000$ \\
\hline Tohum ekimi & $16-20$ & $320-400$ \\
\hline $\begin{array}{l}\text { Sonbahar ve yaz mevsimin- } \\
\text { de çapalama ve ot alma }\end{array}$ & $100-150$ & $2.000-3.000$ \\
\hline $\begin{array}{l}\text { İki yaşında fidanların } \\
\text { yerlerinden çıkarılıp demet } \\
\text { yapılması }\end{array}$ & $40-50$ & $800-1.000$ \\
\hline $\begin{array}{l}\text { 3-6 ay zarfinda toplam } 15 \\
\text { defa su verilmesi }\end{array}$ & $150-250$ & $3.000-5.000$ \\
\hline $\begin{array}{l}\text { Alet, edevat ve diğer mas- } \\
\text { raflar }\end{array}$ & - & $800-1.000$ \\
\hline $\begin{array}{l}\text { Genel tesis giderinin } \% 9 \\
\text { senelik faizi }\end{array}$ & - & $3.716-4.725$ \\
\hline Genel Toplam & & $11.636-17.125$ \\
\hline
\end{tabular}

Tablo 4. İkinci üretim varsayımına göre yapılacak zorunlu masraflar

Table 4. Necessary costs incurred by the second production assumption

\begin{tabular}{lcc}
\hline Çalışma konusu & $\begin{array}{c}\text { Yevmiye } \\
\text { adedi }\end{array}$ & $\begin{array}{c}\text { Yevmiye } \\
\text { tutarı kuruş }\end{array}$ \\
\hline $\begin{array}{l}\text { Tohum bedeli }(1.500 \mathrm{~kg}) \\
\begin{array}{l}\text { Parsellerin toprak işle- } \\
\text { mesi }\end{array}\end{array}$ & - & - \\
$\begin{array}{l}\text { Tohum ekimi } \\
\text { İki senelik fidanların }\end{array}$ & $16-20$ & $1.000-2.000$ \\
yerlerinden çıkarılması & $40-50$ & $800-400$ \\
$\begin{array}{l}\text { Sulama } \\
\text { Çapalama ve temizlik }\end{array}$ & $150-1.000$ \\
Alet ve edevat & - & $3.000-5.000$ \\
Ara toplam & - & $7.000-3.000$ \\
$\begin{array}{l}\text { Genel tesis giderinin } \% 9 \\
\text { senelik faizi }\end{array}$ & - & $3.716-4.725$ \\
\hline Genel Toplam & & $11.636-17.125$ \\
\hline
\end{tabular}

En az sayıda fidan üretilirse, karaçam ve meşe fidan üretim maliyeti 46,54-68,50 kuruş arasında olacaktır. 
En fazla sayıda fidan üretilirse, maliyet düşecek ve 12,93-19,02 kuruş arasında olacaktır.

\section{Dördüncü üretim varsayımı ve maliyet hesabı}

Dördüncü üretim varsayımında şaşırtma işlemi yapılmış 3 yaşında karaçam fidanı yetiştirmenin maliyet hesabı yapılmıştır. Mehmet Tevfik Bey, ekim yastıklarındaki fidanların boylu fidan elde etmek amacı ile sökülüp, daha geniş aralık ve mesafe ile başka parsellere dikilme işlemi için fideleme (şaşırtma) terimini kullanmıştır. Ancak Mehmet Tevfik Bey, köklerin kalınlaşması, sökülme ve taşımada zararların ortaya çıkması ve dikim esnasında büyük çukur açmak gibi zorlukların olması nedeniyle bu üretim şeklini tavsiye etmemektedir. Birinci üretim varsayımında olduğu gibi, karaçam yetiştirmenin ve doğrudan dikim yapılacak sahaya götürmenin daha uygun olacağını belirtmiştir. Yine de böyle bir üretim yapılmak istenirse, 50-60 $\mathrm{cm}$ derinlikte toprak işlemesi yapılması ve 100-150 yevmiye bedeli olan 2.000-3.000 kuruşun maliyete eklenmesini önermiştir.

Ekim yastığında çimlendikten sonra 1 yaşını tamamlayan fidanların, birbirinden $5 \mathrm{~cm}$ arayla ve iki çizgi arasında $15 \mathrm{~cm}$ bulunacak şekilde, metrekareye 150 fidan dikilmesi gerektiğini yazmıştır. Mehmet Tevfik Bey, şaşırtma yapılan alanları terbiye yastığı olarak tarif etmektedir. Ekim yastığında metrekarede 450 fidan olduğu hesabıyla terbiye yastığının üç kat daha büyük olması gerekeceğine dikkat çekilmiştir. Mehmet Tevfik Bey’e göre; bu sebeple fidanlık üçe bölünerek, her sene 0,34 hektarlık kısmına ekim yapılmalıdır. Ayrıca her sene fidan alınmak istenirse fidanlık 0,125 hektarlık sekiz eşit kısma bölünür. İlk sene 1 numaralı parsele tohum ekimi yapılır ve bir yıl sonra yetişen fidanlar 2, 3 ve 4 numaralı terbiye yastıklarına dikilir. Aynı zamanda 8 numaralı parsele tohum ekimi ve boşaltılan 1 numaralı parsele ise toprağın verim gücünü artırmak amacıyla acı bakla adı verilen Lupinus ekilir. Üçüncü sene başında 1 yaşını doldurmuş 8 numaralı parseldeki fidanlar kaldırılıp 5, 6 ve 7 numaralı parsellere dikim yapılır. $\mathrm{Bu}$ kez verim gücü artırılmış bir numaralı parsele yeniden tohum ekimi yapılır, ayrıca 8 numaralı parsele acı bakla ekimi yapılarak dönüşüm sağlanmış olur. Mehmet Tevfik Bey, böylece fidanlıktan her sene düzenli şekilde fidan üretmek mümkün olacağını ifade etmiştir. Ekim dönüşüm planı Tablo 5'te verilmiştir.

$\mathrm{Bu}$ şekilde dördüncü senenin başlangıcından itibaren her sene fidanlığın 3/8'i yani 0,375 hektarından faydalanılır. Parselin 1/3'ü yollar ile hendeklerden meydana geldiğine göre geriye kalan 0,250 hektar k1sımda metrekareye 150 fidandan hesap edilirse, $150 \times 2.500 \mathrm{~m}^{2}=375.000$ fidan elde edilecektir.
Bunun \%10 kısmı zayii olabileceği göz önüne alınırsa 337.500 fidan üretilmiş olacaktır. Yapılacak harcamaların tümü Tablo 6'da gösterilmiştir.

Tablo 5. Dördüncü üretim varsayımına göre ekim dönüşüm planı

Table 5. Sowing rotation plan according to fourth production assumption

\begin{tabular}{cl}
\hline $\begin{array}{c}\text { Parsel } \\
\text { No }\end{array}$ & Yapılacak işler \\
\hline 1 & $\begin{array}{l}\text { Birinci sene tohum ekimi, ikinci sene acı } \\
\text { bakla ekimi, üçüncü sene tohum ekimi }\end{array}$ \\
2 & $\begin{array}{l}\text { İkinci sene bir numaralı ekim yastığından } \\
\text { gelen fidanları dikmek }\end{array}$ \\
3 & $\begin{array}{l}\text { İkinci sene bir numaralı ekim yastığından } \\
\text { gelen fidanları dikmek }\end{array}$ \\
4 & $\begin{array}{l}\text { İkinci sene bir numaralı ekim yastığından } \\
\text { gelen fidanları dikmek }\end{array}$ \\
5 & $\begin{array}{l}\text { Üçüncü sene sekiz numaralı ekim yastığından } \\
\text { gelen fidanları dikmek }\end{array}$ \\
6 & $\begin{array}{l}\text { Üçüncü sene sekiz numaralı ekim yastığından } \\
\text { gelen fidanları dikmek }\end{array}$ \\
7 & $\begin{array}{l}\text { Üçüncü sene sekiznumaralı ekim yastığından } \\
\text { gelen fidanları dikmek }\end{array}$ \\
8 & $\begin{array}{l}\text { İkinci sene tohum ekimi, üçüncü sene acı } \\
\text { bakla ekimi, dördüncü sene tohum ekimi }\end{array}$ \\
\hline
\end{tabular}

Tablo 6. Dördüncü üretim varsayımına göre yapılacak zorunlu masraflar

Table 6. Necessary costs incurred by the fourth production assumption

\begin{tabular}{lcc}
\hline Çalışma konusu & $\begin{array}{c}\text { Yevmiye } \\
\text { adedi }\end{array}$ & \multicolumn{1}{c}{$\begin{array}{c}\text { Yevmiye } \\
\text { tutarı (kuruş) }\end{array}$} \\
\hline $\begin{array}{l}\text { Tohum bedeli (48kg) } \\
40 \text { cm derinliğinde toprak }\end{array}$ & \multicolumn{1}{c}{-} & \multicolumn{1}{c}{-} \\
$\begin{array}{l}\text { işlemesi, taksim, tırmıklama, } \\
\text { tesviye masrafı }\end{array}$ & $50-100$ & $1.000-2.000$ \\
$\begin{array}{l}\text { 2-3 defa sonbahar ve yaz mev- } \\
\text { siminde ot alma ve çapalama }\end{array}$ & $100-150$ & $2.000-3.000$ \\
$\begin{array}{l}\text { Bir yaşındaki fidanların yer } \\
\text { değiştirilmesi }\end{array}$ & $200-300$ & $4.000-6.000$ \\
$\begin{array}{l}\text { 3-6 ay boyunca günaşırı su- } \\
\text { lama }\end{array}$ & $150-250$ & $3.000-5.000$ \\
$\begin{array}{l}3 \text { yaşında fidanların sökülüp } \\
\text { ambalajlanması }\end{array}$ & $50-60$ & $1.000-1.200$ \\
$\begin{array}{l}\text { Alet ve edevat } \\
\text { Toplam }\end{array}$ & - & $800-1.000$ \\
$\begin{array}{l}\text { Genel tesis giderinin \%9 } \\
\text { senelik faizi }\end{array}$ & - & $11.800-18.200$ \\
\hline \begin{tabular}{l} 
Genel Toplam \\
\hline
\end{tabular} & - & $3.896-4.995$ \\
\hline
\end{tabular}

337.500 adet fidanın üretim masrafı en az 15.696 ve en fazla 23.195 kuruş olduğuna göre, 1.000 adet fidanın en az 46,5 kuruş ve 68,73 kuruşa üretilebileceği hesap edilmiştir. 


\section{Beşinci üretim varsayımı ve maliyet hesabı}

Mehmet Tevfik Bey, beşinci üretim varsayımı olarak 3 yaşında fideleme (şaşırtma) yapılmış meşe fidanı yetiştirmenin maliyet hesabını yapmıştır. Meşenin daha ilk senesinde bile köke çalışacağından, bu üretim tarzı tavsiye edilmemektedir. Üretim yapılmak istenirse 1 yaşını tamamlamış fidanların birbirinden $20 \mathrm{~cm}$ mesafe ile metrekareye 36 adet fidan dikilebilecektir. Ancak ekim yastığında 140 adet fidan bulunduğu göz önüne alınırsa, terbiye yastığının dört kat büyük olması gerekir. Bu yöntem ile her sene fidan alınmak istenirse fidanlık 10 eşit parçaya bölünür. İlk sene birinci parsele tohum ekimi yapılır.

İkinci sene yetişmiş fidanlar 2, 3, 4 ve 5 numaralı parsellerde fidelemeye alınır. Aynı zamanda $10 \mathrm{nu}-$ maralı parsele tohum ekimi ve 1 numaralı parsele ise acı bakla ekimi yapılır.

Üçüncü sene başlangıcında 1 yaşını doldurmuş 10 numaralı parselde bulunan meşe fidanları $6,7,8$ ve 9 numaralı terbiye yastıklarında dikim yapılır. Acı bakla ile toprağ 1 kuvvetlendirilmiş 1 numaralı parsele yeniden tohum ekimi ve boşaltılan 10 numaralı parsele acı bakla ekimi yapılır.

Tablo 7. Beşinci üretim varsayımına göre ekim dönüşüm planı

Table 7. Sowing rotation plan according to the fifth production assumption

\begin{tabular}{cl}
\hline $\begin{array}{c}\text { Parsel } \\
\text { No }\end{array}$ & Yapılacak işler \\
\hline 1 & $\begin{array}{l}\text { Birinci sene tohum ekimi, ikinci sene acı bakla } \\
\text { ekimi, üçüncü sene tohum ekimi } \\
2\end{array}$ \\
$\begin{array}{l}\text { İkinci sene bir numaralı ekim yastığından gelen } \\
\text { fidanları dikme } \\
\text { İkinci sene bir numaralı ekim yastığından gelen } \\
\text { fidanları dikme } \\
\text { İkinci sene bir numaralı ekim yastığından gelen } \\
\text { fidanları dikme }\end{array}$ \\
5 & $\begin{array}{l}\text { İkinci sene bir numaralı ekim yastığından gelen } \\
\text { fidanları dikme }\end{array}$ \\
6 & $\begin{array}{l}\text { Üçüncü sene } 10 \text { numaralı ekim yastığından } \\
\text { gelen fidanları dikme }\end{array}$ \\
7 & $\begin{array}{l}\text { Üçüncü sene } 10 \text { numaralı ekim yastığından } \\
\text { gelen fidanları dikme }\end{array}$ \\
8 & $\begin{array}{l}\text { Üçüncü sene } 10 \text { numaralı ekim yastığından } \\
\text { gelen fidanları dikme }\end{array}$ \\
9 & $\begin{array}{l}\text { Üçüncü sene } 10 \text { numaralı ekim yastığından } \\
\text { gelen fidanları dikme } \\
\text { İkinci sene tohum ekimi, üçüncü sene acı bakla } \\
\text { ekimi, dördüncü sene tohum ekimi }\end{array}$ \\
\hline
\end{tabular}

Dördüncü sene 2, 3, 4 ve 5 numaralı terbiye yast1ğında bulunan 3 yaşıııı tamamlamış fidanlar nakledilmek üzere kaldırılır. Böylece döngü Tablo 7'de gösterildiği gibi sağlanmış olur.
İşte bu şekilde dördüncü sene başlangıcından itibaren her sene fidanlığın 0,4 hektarlık kısmından istifade edilebilir. Bu 0,40 hektarın 0,12 hektarı yol ile hendeklere ayrılmış olacağından ekim yastıkları için 0,28 hektar kalacaktır. Metrekareye 36 fidan bulunduğu hesabıyla 0,28 hektarda 100.800 fidan üretilebilecek ve bununda yaklaşı $\% 10$ 'u zayii olursa, geriye 90.800 adet 3 yaşında fidelemeye alınmış meşe fidanı yetiştirilmiş olur. Yapılacak harcamaların tümü Tablo 8'de gösterilmiştir. Bu hesaba göre 90.800 fidanın en az 13.496 ve en fazla 19.995 kuruşa üretilebileceği hesabıyla, 1.000 fidan 148,63 ile 220,20 kuruş arasında üretilebilir.

Tablo 8. Beşinci üretim varsayımına göre yapılacak zorunlu masraflar

Table 8 . Necessary costs incurred by the fifth production assumption

\begin{tabular}{|c|c|c|}
\hline Çalışma konusu & $\begin{array}{l}\text { Yevmiye } \\
\text { adedi }\end{array}$ & $\begin{array}{c}\text { Yevmiye tutarı } \\
\text { (kuruş) }\end{array}$ \\
\hline Tohum $(300 \mathrm{~kg})$ & - & - \\
\hline $\begin{array}{l}40 \mathrm{~cm} \text { derinliğinde toprak } \\
\text { işlemesi }\end{array}$ & $50-100$ & $1.000-2.000$ \\
\hline $\begin{array}{l}\text { Yaz ve son baharda ot alma } \\
\text { ve çapalama }\end{array}$ & $100-150$ & $2.000-3.000$ \\
\hline $\begin{array}{l}\text { Bir senelik fidanların söküm } \\
\text { ve dikimi }\end{array}$ & $100-150$ & $2.000-3.000$ \\
\hline $\begin{array}{l}\text { 3-6 ay boyunca günaşır1 } \\
\text { sulama }\end{array}$ & $150-250$ & $3.000-5.000$ \\
\hline $\begin{array}{l}3 \text { senelik fidanların sökümü } \\
\text { ve demet yapılması }\end{array}$ & $40-50$ & $800-1.000$ \\
\hline Alet edevat ve çivi masrafi & - & $800-1.000$ \\
\hline Ara toplam & - & $9.600-15.000$ \\
\hline $\begin{array}{l}\text { Genel tesis giderinin } \% 9 \\
\text { senelik faizi }\end{array}$ & - & $3.896-4.995$ \\
\hline Genel Toplam & & 13.496-19.995 \\
\hline
\end{tabular}

\section{Altıncı üretim varsayımı ve maliyet hesabı}

Fidelemeye tabi tutularak 3 yaşını tamamlamış karaçam ve meşe karışık fidan yetiştirmek için uygulanır. Sahanın 1/4'ü karaçam ve kalan 3/4'ü meşeye bırakılır. Dördüncü ve beşinci varsayımlara dayanarak 1.000 adet karaçam ve meşe fidanını birlikte üretim maliyetini bulmak mümkündür.

Dördüncü varsayımda karaçam fidanı en az 46,5 kuruş ve en fazla 68,73 kuruş olarak hesaplanmıştı.

Beşinci varsayımda meşe fidanı en az 148,63 ve en fazla 220,20 kuruştan hesaplanmıştı.

Karaçam ve meşe karışık olarak üretildiğinde ise en az 123,01 kuruş ve en fazla 182,33 kuruş olacaktır.

Mehmet Tevfik Bey, giderleri ve arazi kullanımını ikiye katlaması nedeniyle zorunlu olmadıkça fide- 
lemeyi tavsiye etmemektedir. Ağaçlandırma tekniği açısından göknar, sedir, porsuk, sığla, dişbudak, akçaağaç, kayın ve gürgen cinslerinin de fideleme mecburiyeti olduğunu belirtmiştir.

Günümüzde büyük kentlerde park-bahçe tanzimi ve yol kenarı ağaçlandırmalarına büyük önem verilmektedir. Bu nedenle gerek kamu kuruluşları ve gerekse özel kişi ve kuruluşlarca boylu fidanlara büyük miktarlarda talepler olmaktadır. Bu bağlamda özellikle Devlet orman fidanlıklarının üretim alanları müsait olduğu takdirde piyasanın bu çeşit fidan isteklerinin karşılanabilmesi için şaşırtma yöntemiyle boylu fidan üretimi yapılmaktadır (AGM, 1996).

\subsection{Tohumların seçimi, toplanması ve muhafazasına ait tarifname}

Ekilecek tohumlarin memleketin her yerinde kolayca bulunacağından bedelsiz olarak hesaplanmasına rağmen, fidanlığın kurulduğu ilk yıl taşradan gelen tohumların birçoğunun rastgele toplandığ 1 , kalitesiz ve ekime uygun olmadığı anlaşılmıştır (Anonim, 1916c). Bunun üzerine "Tohumların Seçimi, Toplanması ve Muhafazasına Ait Tarifname" hazırlanarak tohumların tarifname doğrultusunda toplanmasını ve kontrol edildikten sonra ekte bulunan " $T$ " cetveline göre bilgisinin girilmesi istenmiştir. Cetvelde, tohumun toplandığı yerin adı, rakımı, enlem-boylamı, iklim bilgileri, arazi eğimi, jeolojik yapısı, toprak derinliği, bitki örtü kalınlığı, rutubetkuraklık bilgisi, ağaç cinsi, ağacın yaşı, tohum adedi, tohum ağırlı̆̆ 1 , toplanma tarihi, tohumların kontrol tarihi, tohumların adedi, çimlenen tohum sayısı, küflenen tohum sayısı ve çimlenme yüzdesi gibi bilgilerin girileceği alanlar vardır (Anonim, 1917). Ekilecek tohum miktarı günümüzde kabul görmüş tohum miktarına yakındır. Ekilecek tohum miktarı, fidan sıklığını ve sonuçta fidan kalitesini etkilemektedir (Boydak ve Çalışkan, 2014).

\subsection{Günümüz birim fiyatlarına göre Hendek Fidanlığının kuruluş ve fidan maliyetleri}

1917 yılı Hendek Fidanlığının kuruluş ve fidan maliyetlerinin günümüze göre hesaplanmasında Osmanlı kuruşları 16,53 ile çarpılmıştır. Dolayısıyla Mehmet Tevfik Bey’in tarif ettiği şekilde bir fidanlığın kuruluş maliyeti dönüşüm sonucunda 682.524 ile 867.825 TL arasında olmaktadır. Günümüzde ise aynı işlem bugünkü rayiçlere göre hesaplandığında Tablo 9'da görüldüğü gibi fidanlığın kuruluş maliyeti 459.000 TL olmaktadır.

Fidan üretim bedellerini karşılaștırmak için birinci üretim varsayımıyla elde edilen fidanları karşılaştırmak yeterli olacaktır. 500.000 fidan üretilirse 1.000 fidan bedeli dönüşüm katsayısı ile çarpıl- dığında en az 384,65 Türk lirası veya en yüksek 566,15 Türk lirası arasında olacaktır. Bunun yerine 1.500 .000 fidan üretilirse 1.000 fidan bedeli en az 128,27 Türk lirası ve en fazla 188,60 Türk lirası arasında olacaktır.

Tablo 9. 2019 fiyatlarına göre bir hektar orman fidanlığı kuruluş maliyeti

Table 9. Establishment cost of one hectare forest nursery by 2019 prices

\begin{tabular}{|c|c|c|}
\hline Yapılacak işin cinsi & Rayiç & $\begin{array}{c}\text { Maliyet } \\
\text { bedeli (TL) }\end{array}$ \\
\hline Arazi Bedeli & Piyasa & 150.000 \\
\hline $\begin{array}{l}\text { Örtü temizliği (ot alma, atık } \\
\text { toplama vs) }\end{array}$ & OGM & 600 \\
\hline Toprak işlemesi (makineli) & OGM & 400 \\
\hline $\begin{array}{l}\text { Su yolu ve kuyuların kazılma- } \\
\text { S1 (makineli) }\end{array}$ & ÇŞB & 250 \\
\hline Hendeğin kazılması (makineli) & ÇŞB & 750 \\
\hline $\begin{array}{l}\text { Parmaklık ve diğer tüm ahşap } \\
\text { malzeme }\end{array}$ & ÇŞB & 21.000 \\
\hline $\begin{array}{l}\text { Arazinin parsellere ayrilmas1 } \\
\text { ve hazırlanmas1 }\end{array}$ & OGM & 6.000 \\
\hline Ekim & OGM & 5.000 \\
\hline $\begin{array}{l}\text { Çapalama ve temizlik için } \\
\text { kadın işçi }\end{array}$ & OGM & 5.000 \\
\hline Alet ve edevat & Piyasa & 45.000 \\
\hline $\begin{array}{l}\text { Bodrumlu bina, işçi barınağ } \\
\text { ve gölgelik alan inşaat masrafi* }\end{array}$ & ÇŞB & 225.000 \\
\hline Toplam & & 459.000 \\
\hline
\end{tabular}

Orman Genel Müdürlüğünün kurumsal internet sitesinde $2+0$ yaşında karaçam fidanının tanesi 0,4-0,5 Türk lirası arasında satılmaktadır (OGM, 2019a). Ancak bağlı birimlerine ise 0,42 Türk lirasindan verilmektedir. Bu fiyatlara göre 1.000 adet fidan 400-500 Türk lirası arasında satılmaktadır.

\section{Tartışma ve Sonuç}

Mehmet Tevfik Bey, raporun birinci bölümünde bir fidanlık kurulması için gereken iş ve işlemler ile yapılacak zorunlu harcamaları detaylı şekilde anlatmıştır. Bir hektar büyüklüğünde fidanlığın kuruluş maliyeti Tablo 2'de gösterildiği gibi 41.29052.500 kuruştur. Bu rakam 1900 yılında Bahçeköy yakınlarında kurulmak istenen fidanlık için talep edilen 50.000 kuruş ödenek ile örtüşmektedir (Anonim, 1900). Ancak Hendek Fidanlığ1 için bekçi ve teknik eleman gibi yönetim ve personel giderleri ayrıca hesaplanmamıştır. Günümüzde ise Tablo 9'da gösterildiği gibi fidanlık kuruluşu için gereken parasal miktar ile 1917 rakamları birbirine çok yakındır. Aynı durum fidan üretim maliyetleri 
için de geçerlidir. Örneğin birinci üretim varsay1mına göre üretilen 2 yaşında karaçam fidan maliyeti ile günümüz 2 yaşındaki karaçam fidan üretim maliyetleri arasında bariz bir fark yoktur.

Üretim varsayımlarından anlaşılacağı üzere, Hendek fidanlığında ibreli olarak karaçam ve yapraklı olarak meşe fidanı yetiştirilmiştir. Bu bakımdan Mehmet Tevfik Bey 2-3 yaşlı karaçam ve meşe fidanları ayrı ayrı veya birlikte normal-şaşırtılmış olarak yetiştirmenin maliyet hesaplarını yapmıştır. Fakat zorunlu giderler ile üretilebilecek fidan sayısını ortalama bir değerden almak yerine asgari veya azami değerlerinin kullanılmış olması görünüşte ciddi bir karmaşaya sebebiyet vermiştir. Aslında bu durum varsayım içinde başka varsayımları ortaya çıkarmıştır. Mehmet Tevfik Bey bu sorunu aşmak için tablolardan faydalanmış, ancak yine de hesapların anlaşılması kolaylaşmamıştır. Muhtemelen Mehmet Tevfik Bey hesaplamaların gerçeğe yakın olması için ortalama değer almaktan kaçınmıştır. Aslında Fidanlıklarda maliyet hesabı yapmak göründüğü kadar kolay değildir. Orman Genel Müdürlüğü orman fidanlıklarında maliyet hesaplarının nasıl yapılacağını açıklamıştır (OGM, 1986). Ayrica Alkan (2000) Eğirdir fidanlığında, Özen (2008) Eskişehir fidanlığında ve Kurt (2014) Afyonkarahisar fidanlığında maliyet analizi yapmıştır. Modern üretim yöntemlerinde maliyet hesabı işçi çalışma zamanı ve makineli çalışma zamanı gibi girdilerin tekrarlı ölçme yöntemiyle matematiksel formüllerle tespit edilmektedir (Kobu, 2003). Bu sebeple Mehmet Tevfik Bey'in maliyet hesapları dönemine göre özgün ve başarılı bir yöntemdir.

Tevfik Bey'in raporunu önemli yapan bir başka husus, tek bir üretim anlayışıyla yetinmeden, farklı seçenekleri dikkate almasıdır. Üstelik Tevfik bey, bugün de genellikle ihmal edilen olasılıklara göre karar vermeyi önemsemiş ve maliyetleri bir aralık için ele almıştır. Günümüz proje tasarım ve değerlendirmelerinde de çoklukla ihmal edilen böylesi bir bakışın 102 yıl önce Tevfik bey tarafından uygulanmış olması, birikimli olduğu kadar, soyutlama ve olasılıklar dahilinde düşünebilme becerilerine sahip biri olduğunu göstermektedir.

Fidanlıklarda kaliteli fidanı ekonomik şekilde yetiştirmek esastır. Bunun için fidan boyu ve fidan kök çevresi veya genel ifade ile kök/sak dengesi önemlidir. Bir başka önemli özellik ise sürdürülebilir kalite yönetimidir. Bu bakımdan fidanlık yerine fidanlık işletmesi terimi tercih edilebilir (Saatçioğlu, 1976). Bir müessesenin ayakta kalması için işletme yönü ihmal edilmemelidir. Mehmet Tevfik Bey, bu hususu mümkün olduğunca göz önünde bulundurarak hesaplamalar yapmıştır. Birinci Dünya Savaşı'nın getirdiği ekonomik zorlukları ve yüksek enflasyon nedeniyle 22 Mart 1303 (3 Nisan 1887) tarihli Murâbaha Nizamnâmesine göre \%9 ile sınırlandırılmış faiz bedeli hesaplamalara eklenmiştir.

Mehmet Tevfik Bey, raporunda daha çok maliyet konusuna odaklanmış ve fidan üretimi konusunda çok detay vermiştir. Buna rağmen fidan üretim yöntemleri günümüzle karşılaştırıldığında, birinci üretim varsayımında tarif edildiği gibi aynı yerde sürekli fidan üretmek yerine rotasyon planlarına göre üretim yapılmaktadır. İkinci üretim varsayımına göre meşe fidanları kazık kök yapmaları nedeniyle 1 yaşından sonra parsellerden kaldırılmaktadır. Üçüncü varsayımda olduğu gibi aynı yerde ve yan yana ibreli ve yapraklı fidan üretilmesi söz konusu değildir. Zira iğne yapraklı ve yayvan yapraklı türlerin toprak ve su istekleri farklıdır. Dördüncü üretim varsayımına göre karaçam üretilmesi halinde en fazla 2 yaşına kadar fidanlar parselde tutulmaktadır. Beşinci üretim varsayımına göre meşe fidanları bugün de aynı şekilde bir yıldan sonra şaşırtmaya tabi tutularak üretilmektedir. Altıncı üretim varsayımında ibreli ve yapraklı fidanların yan yana 3 yaşına kadar üretilmesi, toprak ve su isteklerinin yanında fidanların kök yapıları sebebiyle uygun değildir.

Mehmet Tevfik Bey’in, ekim dönüşüm planında yeşil gübre olarak baklagillerden acı bakla kullanılmasını istemesi fidanlığın teknik bilgilere göre tesis edildiği göstermektedir. Yeşil gübreleme ucuz olup toprağın organik madde içeriğini artırmakta ve fiziksel özelliklerini iyileştirmektedir. Özellikle ağır topraklara geçirgenlik kazandırması, havalandırma sağlaması ve drenajı kolaylaştırması çok önemlidir. Ayrıca azotça fakir topraklarda kök yumrularıyla azot bağlaması oldukça etkilidir (Ürgenç, 1998).

Fidanlığın sulanması için su borularıyla şebeke kurmak yerine, kuyu veya havuzlarda biriken suyun salma şeklinde veya el tulumbası ile yapılması planlanmıştır. Fare gibi kemiricilerle mücadelede zehir veya tiksindirici koymak yerine yine hendekler kazılması önerilmiştir. Bugün kemiricilere karşı mücadelede zehir kullanılmakta olup nadiren koruyucu hendek kazılmaktadır. Bu yöntemde hendek tabanına 3-5 $\mathrm{m}$ ara ile saksılar gömülüp saksıya düşen fareler toplanarak imha edilmekte$\operatorname{dir}$ (AGM, 1996).

Raporda parsellerin çapalanması ile yol ve hendeklerin düzenlenmesinde kadın işçilerin çalıştırıldığı anlaşılmaktadır. Kadın işçi yevmiyesi 15 kuruş olup erkek işçi yevmiyesinden 5 kuruş daha eksiktir. Fakat buradaki tercihin parayla alakalı olmadığı düşünülmektedir. Çapalamada kadınların 
erkeklere göre daha mahir oldukları herkesçe bilinmektedir. Bu sebeple bugün dahi fidanlıklarda kadın işçiler tercih edilmektedir.

Hendek Orman Fidanlığı'nın kuruluşundan elde edilen tecrübe Türk ormancılık tarihi ve bunun altında yer alan orman fidanlıklarının tarihi bakımından çok değerlidir. $\mathrm{Bu}$ fidanlıkta üretilen fidanlar ve kazanılan tecrübeler Türkiye Cumhuriyeti'nin ilk 10 yılında başlatmış olduğu ağaçlandırma ve fidanlık çalışmalarına büyük katkı sağlamıştır. Başkent Ankara'nın ağaçlandırılması ve Atatürk Orman Çiftliğinin yeşillendirilmesi için 1925 yılında kurulan Ankara Orman Fidanlığı'nın tesisinde Hendek tecrübesinden yararlanılmıştır. Fidanlık ve ağaçlandırma faaliyetlerinin kesintisiz devamı ve bugün gelinen yerin takdiri için sınırlı imkânlara rağmen ilk fidanlıkların kuruluşundaki heyecan ve gayretin yeniden tanınması ve keşfedilmesi gereklidir.

\section{Kaynaklar}

AGM., 1996. Orman Fidanlıklarında Teknik Çalıșma Esasları. Ağaçlandırma ve Erozyon Kontrolü Genel Müdürlüğü Yayınları, Ankara.

Alkan, H., 2000. Eğirdir Orman Fidanlığında Fidan Maliyet Analizleri. SDÜ Orman Fakültesi Dergisi. (1): 1-20.

Anonim., 1893. T.C. Cumhurbaşkanlığ 1 Devlet Arşivleri Başkanlığı Osmanlı Arşivi. İrade Orman ve Maadin $1 / 29$.

Anonim., 1900. T.C. Cumhurbaşkanlığı Devlet Arşivleri Başkanlığ ${ }_{1}$ Osmanlı Arşivi. Şura-yı Devlet 529/11.

Anonim., 1910. T.C. Cumhurbaşkanlığı Devlet Arşivleri Başkanlığ 1 Osmanlı Arşivi. İrade Orman ve Maadin $14 / 10$.

Anonim., 1911. Devlet Salnâmesi sene 1329, 412.

Anonim., 1913a. Orman Kısmı. Orman Yetiştirilmek Üzere Vilayete Yazılan Tahriratı Umumiye. Ticaret ve Ziraat Nezareti Mecmuası. (26) 3.

Anonim., 1913b. Orman Yetiştirmek Usulü. Ticaret ve Ziraat Nezâreti Yayınları. Matbaa-i Osmaniye, İstanbul.

Anonim., 1913c. T.C. Cumhurbaşkanlığı Devlet Arşivleri Başkanlığı Osmanlı Arşivi. İrade Ticaret ve Ziraat.1/28-29.

Anonim., 1913d. T.C. Cumhurbaşkanlığı Devlet Arşivleri Başkanlığı Osmanlı Arşivi. İrade Dosya Usulü 54/53.

Anonim., 1914. T.C. Cumhurbaşkanlığı Devlet Arşivleri Başkanlığ1 Osmanlı Arşivi. İrade Ticaret ve Ziraat.1/34

Anonim., 1916a. T.C. Cumhurbaşkanlığı Devlet Arşivleri Başkanlığ 1 Osmanlı Arşivi. Ticaret, Nafia, Ziraat, Orman ve Maadin Nezaretleri 1708/109.
Anonim., 1916b. T.C. Cumhurbaşkanlığ1 Devlet Arşivleri Başkanlığı Osmanlı Arşivi. Ticaret, Nafia, Ziraat, Orman ve Maadin Nezaretleri 1707/631.

Anonim., 1916c. T.C. Cumhurbaşkanlığı Devlet Arşivleri Başkanlığı Osmanlı Arşivi. Ticaret, Nafia, Ziraat, Orman ve Maadin Nezaretleri 1708/109.

Anonim., 1917. Başlıca Orman Teșkil Eden Eșcarın Tohumlarının Sureti İntihabı ve Cemleriyle Usulü Muhafazalarına Dair Tarifname. Hukuk Matbaası, İstanbul

Anonim., 1918a. Adapazar1 Devlet Ormanlarından Hendek Nahiyesi İdare Mintıkası Ait Amenajman Lâyiha Fenniyesi. Hilal Matbaası, İstanbul.

Anonim., 1918b. Belgrad Ormanları Lâhiyası. Orman Mektebi Alisi Mecmuası (6): 176.

Anonim., 1918c. T.C. Cumhurbaşkanlığı Devlet Arşivleri Başkanlığ 1 Osmanlı Arşivi. Ticaret, Nafia, Ziraat, Orman ve Maadin Nezaretleri 1708/999.

Anonim., 1919. T.C. Cumhurbaşkanlığı Devlet Arşivleri Başkanlığı Osmanlı Arşivi. İrade Dosya Usulü 54/55.

Anonim., 1921. T.C. Cumhurbaşkanlığı Devlet Arşivleri Başkanlığı Osmanlı Arşivi. Şura-yı Devlet 1268/12.

Boydak, M., Çalışkan, S., 2014. Ağaçlandırma. OGEMVAK Yayınlar1, ISBN:978-975-93943-8-7, Ankara.

ÇSB. 2019a. Çevre ve Şehircilik Bakanlığı, İnşaat ve Tesisat Birim Fiyatları. https://yfk.csb.gov.tr/2019-yiliyayinlarimiz-i-91515 (Ziyaret tarihi: 10.06.2019).

ÇSB. 2019b. Çevre ve Şehircilik Bakanlığı, Mimarlık ve Mühendislik Hizmet Bedellerinin Hesabında Kullanılacak 2019 Yılı Yap1 Yaklaşık Birim Maliyetleri Hakkında Tebliği. http://www.resmigazete.gov. tr/eskiler/2019/03/20190316-12.htm (Ziyaret tarihi: 10.06.2019).

Diker, M., İnal, S., 1945. Ormancılığımızın Ana Davalarından Ağaçlandırma. Ankara Yüksek Ziraat Enstitü Dergisi, (9) 1.

Ergin, F., 2017. Birinci Dünya Savaşı'nda ve Atatürk Döneminde Fiyatlar ve Gelirler. https://atam.gov.tr (Ziyaret tarihi: 10.06.2019).

Hermann., 1894. Tarım Raporları, Ankara Şimendifer hattı güzergahında yapılacak zirai faaliyetleri için verilen rapor. Matbaa-i de Castro, İstanbul.

İhsan., 1917. Ormanlarımızın Tarihçesi. Orman Mektebi Alisi Mecmuası, (1), 26.

Kobu, B., 2003. Üretim Yönetimi. Avcıol Basım Yayım, İstanbul.

Kurt, İ., 2014. Afyonkarahisar Orman Fidanlık Müdürlüğünde Fidan Üretim Maliyetleri Üzerine Araştırmalar, KMÜ Fen Bilimleri Enstitüsü, Basılmamış Yüksek Lisans Tezi.

Kutluk, H., Yund, K., 1950. Hoca Ali Riza Orman 
Umum Müdürlerinden Hayatı ve Eserleri 1843-1925. Verim Yayınları, Ankara.

Kutluk, H., 1957. Türkiye'de Yabancı Ormancılar. Türk ormanc1lığ1 yüzüncü tedris y1lına girerken 1857-1957 (sayfa 189). Türkiye Ormancılar Cemiyeti Yayınları, Ankara.

Kutluk, H., 1967. Türkiye Ormancıllı̆̆ İle İlgili Tarihi Vesikalar, Cilt 2. OGM Yayınları, İstanbul.

Mehmet Tevfik ., 1917. Fidanl1k Tesisi. Orman Mektebi Alisi Mecmuası (3), 26.

OGM., 1986. Fidanlık Çalışmaları. Yayın ve Tanıtım Şube Müdürlüğü Matbaası, Ankara.

OGM. 2018. Orman Genel Müdürlüğü 2018 Yılı İdare Faaliyet Raporu, 39.

OGM. 2019a. Orman Genel Müdürlüğü 2019 Y1lı Fidan ve Tohum Satış Fiyatları. https://fidanstoksorgulama. ogm.gov.tr (Ziyaret tarihi: 10.06.2019).
OGM. 2019b. Orman Genel Müdürlüğü Ağaçlandırma Rehabilitasyon, Toprak Muhafaza, Erozyon ve Sel Kontrolü, Mera Islahı, Kavak Ağaçlandırması, Fidanlık, Silvikültür ve Etüt Proje Birim Fiyat Cetveli. https://www. ogm.gov.tr/Lists/Duyurular/DispForm.aspx?ID=960 (Ziyaret tarihi: 10.06.2019).

Ortaç, T., 1945. Ormanc1 Postası Gazetesi (37).

Özen, F., 2008. Orman Fidanlığında Fidan Maliyeti Analizi. İÜ Fen Bilimleri Enstitüsü, Basılmamış Yüksek Lisans Tezi.

Saatçioğlu, F., 1976. Fidanlık Tekniği. Sermet Matbaas1, İstanbul

Ürgenç, S., 1998. Ağaç ve Süs Bitkileri Fidanlık ve Fetiştirme Tekniği. İ.Ü Orman Fakültesi Yayınları, ISBN: 975-404-445-7, İstanbul.

Yund, K., 1959. Türkiye Orman Umum Müdürleri Albümü. Hüsnü Tabiat Yayınevi, İstanbul. 